\title{
Effect of Temperature on Penetration and Multiplication of Root-Knot Nematode, Meloidogyne Incognita on Tomato
}

\author{
Kshetrimayum Sumita ${ }^{1} *$ and Debanand Das $^{2}$ \\ ${ }^{1}$ Directorate of Research, Central Agricultural University, 795004, Manipur, India \\ ${ }^{2}$ Department of Nematology, Assam Agricultural University, Jorhat-785013, Assam, India
}

Corresponding author

\begin{tabular}{|c|c|}
\hline & A B S T R A C T \\
\hline $\begin{array}{l}\text { Second stage juvenile } \\
\left(\mathrm{J}_{2}\right) \text { Meloidogyne } \\
\text { incognita, Penetration, } \\
\text { Multiplication, } \\
\text { Temperature }\end{array}$ & \multirow{3}{*}{$\begin{array}{l}\text { Penetration was not affected by temperature but, migration and post- } \\
\text { penetration inside the root tissue were influenced by temperature. At } \\
27 \pm 1^{\circ} \mathrm{C}, M \text {. incognita second stage juvenile }\left(\mathrm{J}_{2}\right) \text { took } 5 \text { days to reached } \\
\text { stele region followed by } 31 \pm 1^{\circ} \mathrm{C} \text { and } 23 \pm 1^{\circ} \mathrm{C}(7 \text { days }) \text { while, at } 21 \pm 1^{\circ} \mathrm{C} \text {, it } \\
\text { took } 10 \text { days. Multiplication of } M \text {. incognita was greatly affected by } \\
\text { temperature. Maximum number of galls per root system }(119.6) \text {, number of } \\
\text { egg masses per root system }(275.2) \text {, number of eggs per egg mass }(343.6) \text {, } \\
\text { final nematode population }(1335.2) \text { and reproduction factor of nematodes } \\
\text { (2.67) was observed at } 27 \pm 1^{\circ} \mathrm{C} \text { followed by } 31 \pm 1^{\circ} \mathrm{C}, 23 \pm 1^{\circ} \mathrm{C} \text { and } 21 \pm 1^{\circ} \mathrm{C} \\
\text { respectively. }\end{array}$} \\
\hline Article Info & \\
\hline $\begin{array}{l}\text { Accepted: } \\
\text { 15 June } 2018 \\
\text { Available Online: } \\
10 \text { July } 2018\end{array}$ & \\
\hline
\end{tabular}

\section{Introduction}

Plant parasitic nematodes belonging to the family Meloidogynidae (Order: Tylenchida) are obligate sedentary endoparasite widely distributed in both tropical and temperate climate. The infective second stage juvenile $\left(\mathrm{J}_{2}\right)$ penetrate into the roots at the zone of elongation and establish feeding sites in the phloem causing disruption, hypertrophy and hyperplasia of cells resulting in formation of giant cells and swellings at the sites of establishment due to which the nutrient uptake of the root is hampered; crop become stunted in growth. Sasser and Carter (1985) reported that root-knot nematodes are responsible for 5 per cent (approximately) global crop loss and estimated yield loss due to Meloidogyne spp., mainly $M$. incognita and $M$. javanica, ranged from 17 to 20 per cent on brinjal, 18 to 33 per cent on melon and 24 to 38 per cent on tomato (Sasser,1979). In India, yield losses due to Meloidogyne spp. in vegetable crops such as okra, tomato and brinjal were estimated to be 91 per cent, 42 to 54 per cent and 18 per cent, respectively (Bhatti and Jain, 1977; Subramaniyan et al., 1990).

\section{Materials and Methods}

Autoclaved soils containing mixture of soil, dried cowdung and sand at 2:1:1 respectively 
was filled in pots of $150 \mathrm{gm}$ capacity (penetration experiment) and 500 gm capacity (multiplication experiment). Three seeds of susceptible tomato (var. Bioseed) were sown to each pot. One week after germination, seedlings were thinned out to one healthy seedling in each pot. $\mathrm{J}_{2}$ of $M$. incognita were inoculated with the help of micro pipette to the feeder root @ 1 $\mathrm{J}_{2} / 1 \mathrm{gm}$ of soil. Inoculated pots were kept in growth chamber at $21 \pm 1^{\circ} \mathrm{C}$, $23 \pm 1^{\circ} \mathrm{C}, 27 \pm 1^{\circ} \mathrm{C}$ and $31 \pm 1^{\circ} \mathrm{Cof}$ Department of Crop Physiology, AAU, Jorhat.

\section{Penetration of $M$. incognita}

Three seedlings were carefully uprooted on time interval starting from one hour after inoculation. The root system was washed very carefully under tap water and teased with the help of a fine needle under stereo-zoom binocular microscope to observe the penetration of juvenile (s) inside the root tissue.

\section{Multiplication of $M$. incognita}

After 45 days of inoculation, plants were uprooted carefully. 200cc of soil was processed from each pot to find out the final soil population of $M$. incognita by the Cobb's sieving and decanting method. Roots were washed carefully under tap water and number of galls per root system, number of egg mass per root system, number of eggs per egg mass, final nematode population and its reproduction factor were recorded at $21 \pm 1^{\circ} \mathrm{C}, 23 \pm 1^{\circ} \mathrm{C}$, $27 \pm 1^{\circ} \mathrm{C}$ and $31 \pm 1^{\circ} \mathrm{C}$. All the treatments were replicated 5 times.

\section{Results and Discussion}

\section{Penetration and post penetration}

In the present investigation, it was observed that temperature does not effect on penetration of $\mathrm{J}_{2}$ M.incognita rather, showed effect on migration inside the root tissue. At all the temperatures $\left(21 \pm 1^{\circ} \mathrm{C}, \quad 23 \pm 1^{\circ} \mathrm{C}, \quad 27 \pm 1^{\circ} \mathrm{C}\right.$ and $31 \pm 1^{\circ} \mathrm{C}$ ), $M$. incognita $\mathrm{J}_{2}$ started to penetrate root within 2 hours of inoculation, just behind the root tip (root cap).At $27 \pm 1^{\circ} \mathrm{C}$, after 4 hours, $\mathrm{J}_{2}$ penetrated fully inside the root epidermis and reached stele region within 5 days resuming the vertical position with tail towards the cortex. But at $31 \pm 1^{\circ} \mathrm{C}$ and $23 \pm 1^{\circ} \mathrm{C}, \mathrm{J}_{2}$ reached stele region within 7 days while, at $21 \pm 1^{\circ} \mathrm{C}$, it took 10 days. Similarly, Mishra et al.(1985) alsoreported that Heteroderazeae $\mathrm{J}_{2}$ penetrated roots within 3 hrs of inoculation, complete penetrationwithin $6 \mathrm{hrs}$ and move to the central portion of root within 5 days but temperature was not mention. Haque and Padmavathy (1985) recorded that $R$. reniformis penetrated both Pusa Ruby and Patriot tomato varieties within 48 to 72 hrs. However, penetration times were found to be significantly different and highest number of juvenile in roots was invariably observed after 96 hrs.

\section{Multiplication of $M$. incognita}

Result presented in Table 1, revealed that all the four treatments at different temperature significantly increased multiplication of M.incognita and decreased in root system. The number of gall per root system (119.6), egg masses per root system (275.2), eggs per egg mass(343.6), final nematode population (1335.2) and reproduction factor (2.67) was found to be maximum at $27 \pm 1^{\circ} \mathrm{C}$ followed by $23 \pm 1^{\circ} \mathrm{C}$ and $31 \pm 1^{\circ} \mathrm{C}$. Minimum number of gall, egg masses, eggs, final nematode population and reproduction factor was recorded in $21 \pm 1^{\circ} \mathrm{C}$.Present study on multiplication of $M$. incognita revealed that temperature influenced the multiplication of $M$. incognita. Similar findings were also observed by Ustinov and Tereshchenko (1959) in Ditylenchus destructor reporting that, temperature influenced the life cycle of $D$. destructor (Fig. 1 and 2). 
Table.1 Effect of temperature on multiplication of $M$. incognita on tomato var. Bioseed

\begin{tabular}{|c|c|c|c|c|c|c|}
\hline $\begin{array}{c}\text { Temperature } \\
\text { levels }\end{array}$ & $\begin{array}{c}\text { No. of } \\
\text { galls/ root } \\
\text { system }\end{array}$ & $\begin{array}{c}\text { No. of } \\
\text { egg mass/ } \\
\text { root } \\
\text { system }\end{array}$ & $\begin{array}{c}\text { No. of } \\
\text { eggs/ egg } \\
\text { mass }\end{array}$ & $\begin{array}{c}\text { Initial } \\
\text { nematode } \\
\text { population/ } \\
200 \text { cc of } \\
\text { soil }\end{array}$ & $\begin{array}{c}\text { Final } \\
\text { nematode } \\
\text { population/ } \\
\text { 200cc of } \\
\text { soil }\end{array}$ & $\begin{array}{l}\text { Reproduction } \\
\text { factor }\end{array}$ \\
\hline $21 \pm 1^{\circ} \mathrm{C}$ & $71.6_{a}$ & $98.6_{a}$ & $246.4_{a}$ & 500 & $687.6_{a}$ & 1.37 \\
\hline $23 \pm 1^{\circ} \mathrm{C}$ & $83.2_{b}$ & $138.2_{\mathrm{b}}$ & $278_{b}$ & 500 & $819.0_{b}$ & 1.63 \\
\hline $27 \pm 1^{\circ} \mathrm{C}$ & $119.6_{c}$ & $275.2_{c}$ & $343.6_{c}$ & 500 & 1335.2 c & 2.67 \\
\hline $31 \pm 1^{\circ} \mathrm{C}$ & $93.8_{d}$ & $171.8_{d}$ & $298.8_{d}$ & 500 & $924.4_{d}$ & 1.84 \\
\hline C. $D=0.05$ & 6.71 & 8.41 & 12.62 & - & 33.72 & - \\
\hline C. $D=0.01$ & 10.96 & 13.73 & 20.60 & - & 55.06 & - \\
\hline
\end{tabular}

Means followed by the same letter shown in the subscript (s) are significantly different

Fig.1 Penetration and post-penetration of $M$. incognita in different root zones A. Initiation of penetration by $J_{2} ; B$. $J_{2}$ near the stele region; C. $J_{2}$ feeding in the stele region

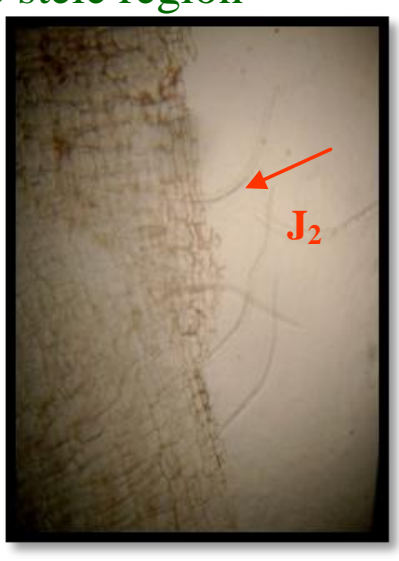

A

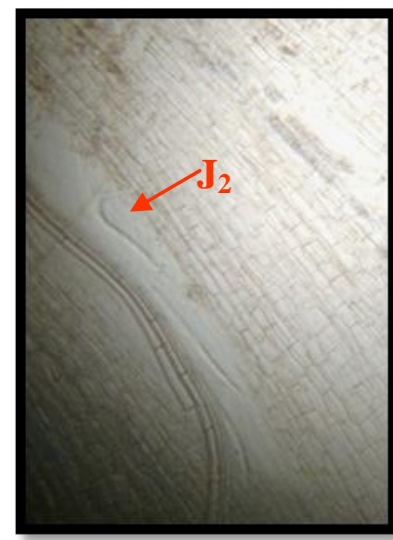

B

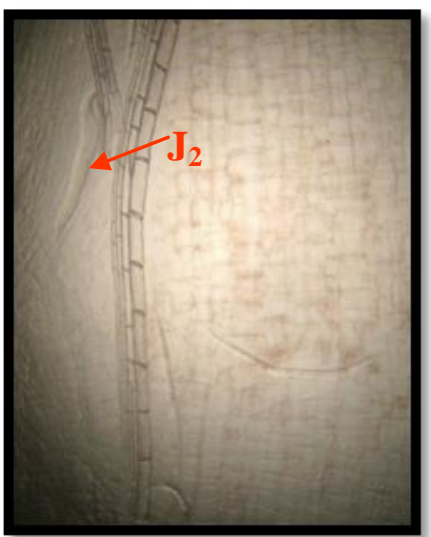

C

Fig.2 Root infected by M. incognita on tomato var. Bioseedat different temperature levels

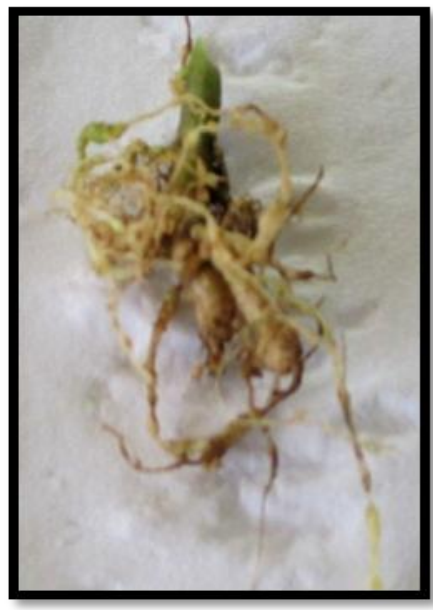

$21 \pm 1^{\circ} \mathrm{C}$

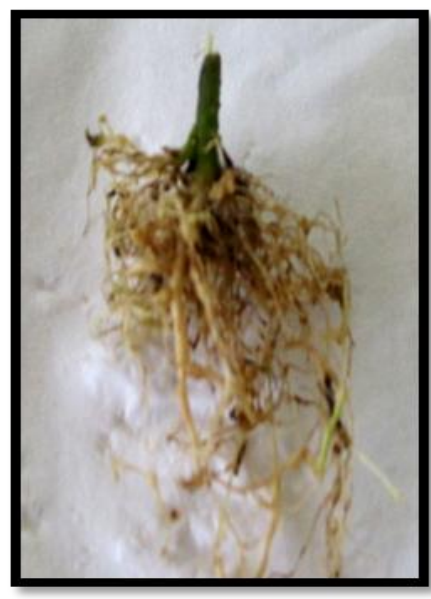

$23 \pm 1^{\circ} \mathrm{C}$

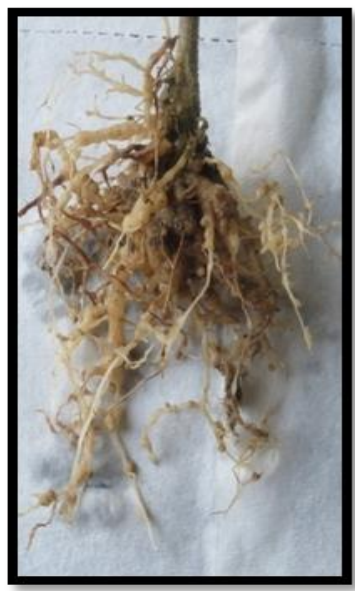

$27 \pm 1^{\circ} \mathrm{C}$

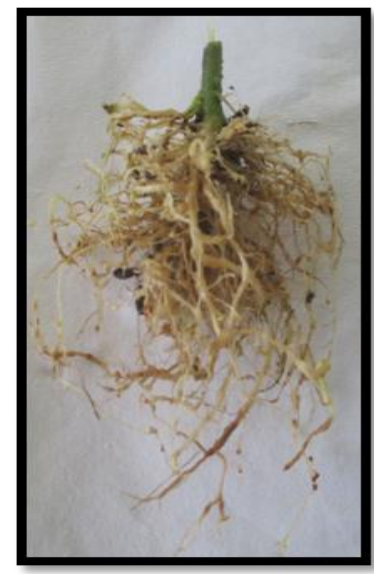

$31 \pm 1^{\circ} \mathrm{C}$ 


\section{References}

Sasser, J.N. and Carter, C.C. (1985). Overview of the International Meloidogyne Project 1975-1984. In: An Advanced Treatise on Meloidogyne. Sasser, J.N. and Carter, C.C. (eds.). Raleigh: North Carolina State University Graphics, pp. 19-24.

Sasser, J.N. (1979). Economic importance of Meloidogyne in tropical countries. In: Root-Knot Nematodes (Meloidogyne species). Lamberti, F. and Taylor, C.E. (eds.). Systematics, Biology and Control, Academic Press, London, UK, pp. 359-374.

Subramaniyan, S.; Ragendra, G. and Vadivelu, S. (1990). Estimation of loss in tomato due to Meloidogyne incognita and Rotylenchulus reniformis. Indian J.Nematol. 20(2): 239-240.

Bhatti, D.S. and Jain, R.K. (1977). Estimation of loss in okra, tomato and brinjal yield due to Meloidogyne incognita. Indian J. Nematol.7(1): 37-41.

Haque, M.M. and Padmavathy, P.V. (1985). Studies on penetration by Rotylenchulus reniformis in relation to age of the seedling and time interval on tomato varieties. Indian $J$. Nematol. 15(1): 112-113.

Mishra, S.N.; Edward, J.C. and Gupta, P. (1985). Histopathology of Heteroderazeae on maize. Indian $J$. Nematol. 15(1): 111-112.

Ustinov, A.A. and Tereshchenko, E.F. (1959). The stem nematode of potato. Zashchita Rasteniiot Vrediteleii Boleznei. 6: 29-31.

\section{How to cite this article:}

Kshetrimayum Sumita and Debanand Das. 2018. Effect of Temperature on Penetration and Multiplication of Root-Knot Nematode, Meloidogyne Incognita on Tomato. Int.J.Curr.Microbiol.App.Sci. 7(07): 1709-1712. doi: https://doi.org/10.20546/ijcmas.2018.707.202 